OPEN ACCESS

Edited by:

Aurelio Cafaro,

Istituto Superiore di Sanità, Italy

Reviewed by:

Namal P. M. Liyanage,

The Ohio State University,

United States

Egidio Brocca Cofano,

University of Pittsburgh,

United States

Heather Beryl Jaspan,

University of Cape Town,

South Africa

*Correspondence: leda Maria Longo-Maugéri

imaugeri@unifesp.br

Specialty section: This article was submitted to HIV and AIDS,

a section of the journal

Frontiers in Immunology

Received: 28 September 2017

Accepted: 19 January 2018

Published: 07 February 2018

Citation:

Teixeira D, Ishimura ME,

Apostólico JdS, Viel JM,

Passarelli VC, Cunha-Neto E, Rosa DS and Longo-Maugéri IM (2018) Propionibacterium acnes

Enhances the Immunogenicity of HIVBr18 Human Immunodeficiency

Virus-1 Vaccine.

Front. Immunol. 9:177. doi: 10.3389/fimmu.2018.00177

\title{
Propionibacterium acnes Enhances the Immunogenicity of HIVBr18 Human Immunodeficiency Virus-1 Vaccine
}

\begin{abstract}
Daniela Teixeira', Mayari Eika Ishimura', Juliana de Souza Apostólico', Jacqueline Miyuki Viel', Victor Cabelho Passarelli', Edecio Cunha-Neto', Daniela Santoro Rosa ${ }^{1}$ and leda Maria Longo-Maugéri ${ }^{1 *}$
\end{abstract}

'Division of Immunology, Department of Microbiology, Immunology and Parasitology, Federal University of São Paulo, São Paulo, Brazil, ${ }^{2}$ Laboratory of Clinical Immunology and Allergy-LIM60, School of Medicine, University of São Paulo, São Paulo, Brazil

Immunization of BALB/c mice with HIVBr18, a DNA vaccine containing $18 \mathrm{CD}^{+} \mathrm{T}$ cell epitopes from human immunodeficiency virus $(\mathrm{HIV})$, induced specific $\mathrm{CD}^{+}$and $\mathrm{CD}^{+}$ $T$ cell responses in a broad, polyfunctional and persistent manner. With the aim of increasing the immunogenicity of this vaccine, the effect of Propionibacterium acnes as an adjuvant was evaluated. The adjuvant effects of this bacterium have been extensively demonstrated in both experimental and clinical settings. Herein, administration of two doses of $\mathrm{HIVBr} 18$, in the presence of $P$. acnes, increased the proliferation of HIV-1specific $\mathrm{CD}^{+}$and $\mathrm{CD} 8^{+} \mathrm{T}$ lymphocytes, the polyfunctional profile of $\mathrm{CD} 4^{+} \mathrm{T}$ cells, the production of IFN- $\gamma$, and the number of recognized vaccine-encoded peptides. One of the bacterial components responsible for most of the adjuvant effects observed was a soluble polysaccharide extracted from the $P$. acnes cell wall. Furthermore, within 10 weeks after immunization, the proliferation of specific T cells and production of IFN- $\gamma$ were maintained when the whole bacterium was administered, demonstrating a greater effect on the longevity of the immune response by $P$. acnes. Even with fewer immunization doses, $P$. acnes was found to be a potent adjuvant capable of potentiating the effects of the HIVBr18 vaccine. Therefore, $P$. acnes may be a potential adjuvant to aid this vaccine in inducing immunity or for therapeutic use.

Keywords: Propionibacterium acnes, adjuvant, human immunodeficiency virus-1, DNA vaccine, CD4 $^{+}{ }^{\top}$ cell, immunomodulation

\section{INTRODUCTION}

Human immunodeficiency virus (HIV) was discovered and characterized more than thirty years ago $(1,2)$, and the epidemic it causes is still a significant public health problem. Despite favorable changes in the incidence of HIV in many countries, data from the World Health Organization estimated that more than 36.7 million people worldwide were living with HIV, and 1.1 million lost their lives to acquired immune deficiency syndrome (AIDS) in 2015 (3).

Adaptive immunity against HIV- 1 infection is mediated by specific $\mathrm{CD} 4^{+}$and $\mathrm{CD} 8^{+}$lymphocytes and by neutralizing and non-neutralizing antibodies $(4,5)$. The contribution of cytotoxic T lymphocytes (CTLs) in the control of viremia has been demonstrated (6). However, although CTLs positively influence the progression of clinical diseases $(7,8)$, CTLs alone are not sufficient to control disease (9). 
$\mathrm{CD}^{+} \mathrm{T}$ lymphocytes, whose mass destruction by infection facilitates the development of the main symptoms of AIDS, can also play a protective role. These cells assist the induction and maintenance of CTL responses, the differentiation of B lymphocytes into plasma cells, and the expansion of memory B cells (10-12). Proliferation of HIV-1-specific CD4 ${ }^{+} \mathrm{T}$ lymphocytes has been shown to be related to decreased viremia by controlling HIV-1 replication (13), and polyfunctional activity of these cells in the mucosal region, as well as the presence of HIV-specific cytotoxic $\mathrm{CD}^{+}{ }^{+} \mathrm{T}$ lymphocytes, may be beneficial during HIV-1 progression (14-18). Moreover, depletion of $\mathrm{CD}^{+} \mathrm{T}$ cells has been shown to result in reduced protection against SIV challenge in SIV-vaccinated non-human primates (19). Due to the importance of the cellular immune response against HIV-1 infection, the development of vaccine candidates targeting conserved $\mathrm{T}$ lymphocyte epitopes, especially of $\mathrm{CD}^{+} \mathrm{T}$ cells, has become relevant $(20,21)$.

In previous reports, our group scanned the entire consensus proteome of HIV-1 subtype B with an algorithm called TEPITOPE, and we mapped $18 \mathrm{HIV}$-1-specific $\mathrm{CD} 4^{+} \mathrm{T}$ cell epitopes that were able to promiscuously bind to different HLA molecules (DR, DQ, and DP) (22). Peripheral blood mononuclear cells from more than $90 \%$ of evaluated HIV patients were able to recognize these peptides. Following this analysis, DNA vaccine HIVBr18, encoding such epitopes, was produced $(23,24)$. Immunization of mice transgenic for common HLA class II molecules with HIVBr18 led to extensive $\mathrm{CD}^{+}$and $\mathrm{CD}^{+} \mathrm{T}$ lymphocyte responses that targeted 16 of 18 encoded epitopes and exhibited a persistent and polyfunctional profile (23). These studies suggested that such a vaccine could have broad coverage in the human population that could in turn recognize multiple HIV-1 peptides.

DNA vaccines have several advantages over recombinant viral vaccines, including being easier to access and cheaper to prepare and having a quicker mode of deployment in case of an emerging infection epidemic. However, the suboptimal immunogenicity of DNA vaccines in humans is a significant drawback and is probably due to inefficient transfection (25). Several approaches have been used to enhance their immunogenicity and enable efficient use in humans (26-28). Indeed, an ideal adjuvant for DNA vaccines should be capable of improving DNA uptake, gene expression, antigen processing and presentation and of modulating both the innate and adaptive immune responses. Some adjuvants are currently being used in clinical trials involving combined use with DNA vaccines, such as glucopyranosyl lipid adjuvant-aqueous formulation (29).

Propionibacterium acnes is a Gram-positive anaerobic bacillus that belongs to the normal cutaneous microbiota (30) and has beneficial immunomodulatory activity when used as a heat- or phenol-killed suspension. Since it is extensively used as an adjuvant in clinical trials, $P$ acnes can be a suitable candidate for vaccine approaches in humans $(31,32)$. Among its main biological activities, $P$. acnes promotes macrophage activation $(33,34)$, exhibits tumoricidal activity (34-39) and induces an adjuvant effect on antibody responses $(40,41)$, which altogether seem to explain the increase in pathogen resistance observed after intraperitoneal or subcutaneous treatment with this bacterium (42-47). The mechanisms responsible for the modulating effects of $P$. acnes on both innate and acquired immunity are mediated by proinflammatory cytokines, which are induced by treatment with this adjuvant in a manner dependent on TLR2, TLR9, and MyD88 (48-51). Due to this cytokine pattern, the killed P. acnes suspension has been used as a Th1 response inducer (52-54).

To investigate which component from $P$. acnes is related to the effects observed with the whole bacterium treatment, a cell wall polysaccharide (PS) purified from this bacterium was characterized by our group (55), and in different models, PS was shown to induce similar effects as those generated by the total bacterial suspension. The heat-killed $P$. acnes suspension and PS were both able to enhance an antibody response to a Trypanosoma cruzi DNA vaccine in mice (41), increase the number and tumoricidal activity of peritoneal macrophages (38), and enhance the number and maturation of dendritic cells (DCs) (56). Furthermore, we revealed that $P$. acnes and PS could not only direct a typical Th1 response but also enhance the elicited Th2 pattern in a murine model of type I hypersensitivity reaction $(55,57)$. Thus, these findings indicate that PS may be one of the leading $P$. acnes components related to its beneficial effects.

The adjuvant effect of $P$. acnes on these experimental models has led to the conclusion that its modulation of the immune response probably occurs by direct action on antigen-presenting cells (APCs) (58). Indeed, the effect of $P$. acnes in recruiting and maturing DCs $(52,56)$ and its immunomodulation of the activation status of APCs, such as B lymphocytes, macrophages and DCs, which are responsible for $\mathrm{T}$ cell direction, have been previously demonstrated (58).

As $P$. acnes has been previously shown to increase the immunogenicity of a DNA vaccine against T. cruzi in mice (41), herein, we investigated whether its association could also improve the immunogenicity of HIVBr18 immunization in BALB/c animals. Moreover, we examined whether PS could be related to one of the mechanisms by which $P$. acnes may function when associated with this vaccine. Due to its approved use in humans, previous use in clinical trials and commercial use in immunotherapy for immunosuppressed patients, $P$. acnes may be a promising adjuvant for increasing the immunogenicity of the DNA vaccine HIVBr18 in humans.

In addition, other adjuvants, such as bupivacaine (59) and a plasmid encoding GM-CSF (60), have also been simultaneously used with HIVBr18 in experimental models. However, although both induced some adjuvant effect, neither bupivacaine nor GM-CSF produced the immunomodulatory effect elicited by $P$. acnes, namely, increasing the magnitude and amplifying the recognition of HIVBr18 epitopes.

\section{MATERIALS AND METHODS}

\section{Animals}

Eight-week-old female BALB/c mice $\left(\mathrm{H}-2^{\mathrm{d}}\right)$ were housed and handled under specific pathogen-free conditions at the animal care facilities of the Immunology Division of Federal University of São Paulo. Animal handling was conducted in strict compliance with the National Institutes of Health Guide for the Care Use of Laboratory Animals and the Brazilian National Law 
(11.794/2008). This study was approved by the Institutional Animal Care and Use Committee of the Federal University of São Paulo (permit number 4836281114).

\section{Adjuvants}

\section{Heat-Killed $P$. acnes Suspension}

Propionibacterium acnes strain was obtained from Adolfo Lutz Institute, SP, Brazil. After three days in culture using anaerobic medium (Hemobac, Probac, SP, Brazil) at $37^{\circ} \mathrm{C}$, bacteria were washed three times at 2,000 $\mathrm{g}$ for $30 \mathrm{~min}$ and then resuspended in saline. The bacterial suspension was autoclaved at $120^{\circ} \mathrm{C}$ for $20 \mathrm{~min}$, and protein concentration was determined using the Bradford method (61) and was then used to establish individual doses for immunization.

\section{$P$. acnes Soluble PS Fraction}

Polysaccharide was obtained by phenol-extraction and ethanol precipitation, as previously described by our group (55) and based on Palmer and Gerlough protocol for PS extraction (62). The Bradford method (61) was used to confirm PS purity with the absence of proteins, and the carbohydrate concentration was determined using the Dubois method (63).

\section{DNA Vaccine}

The DNA vaccine HIVBr18, which was previously described $(23,24)$, was used in this study. This construct was designed to encode sequences for $18 \mathrm{CD}^{+}$epitopes derived from HIV-1 subtype B consensus sequence (22): gag1 to gag4, pol1 to pol3, env1 to env5, rev, vpr2 and vpr3, vif2, vpu, and nef. Large-scale purifications of the empty vector pVAX1 and pVAX-HIVBr18 plasmid were performed using an EndoFree Plasmid Giga Kit (Qiagen) according to the manufacturer's instructions. The obtained DNA was evaluated for yield and purity by spectrophotometry at $260 \mathrm{~nm}$ and by endonuclease digestion with HindIII and XhoI.

\section{Peptides}

The 18 epitopes encoded by the DNA vaccine HIVBr18 were synthesized by solid-phase technology with amidation of the C-terminal carboxyl group (Biomatik). Peptide purity was defined as above $90 \%$.

\section{Immunization Schedule}

Six mice per group were intramuscularly injected with two doses of $100 \mu \mathrm{g}$ of plasmid pVAX-HIVBr18 or empty vector pVAX1 per dose $(1 \mu \mathrm{g} / \mu \mathrm{l}$, in saline) and $50 \mu \mathrm{g}$ for each quadriceps. Doses were administered at an interval of 2 weeks, and each dose was mixed with adjuvants $(70 \mu \mathrm{g}$ of protein of the heat-killed $P$. acnes suspension or $25 \mu \mathrm{g}$ of PS) or with $0.9 \%$ saline. Mice were euthanized, and splenocytes were collected 2 or 10 weeks after the last immunization. Experiments were repeated up to three times.

\section{Cell Isolation for Immune Assays}

Single-cell suspensions of splenocytes from the immunized groups were obtained 2 or 10 weeks after the last immunization by pooling samples from the animals in each group; however, for the cytotoxicity assay, each animal was individually analyzed.
R10 medium (RPMI-1640 supplemented with 10\% fetal bovine serum, $2 \mathrm{mM}$ L-glutamine, $1 \mathrm{mM}$ sodium pyruvate, $1 \%$ vitamin solution, $1 \%$ nonessential amino acids, penicillin/streptomycin, $28 \mathrm{mM}$ HEPES, $23.8 \mathrm{mM}$ sodium bicarbonate, and $55 \mathrm{mM}$ 2-mercaptoethanol, Gibco) was used to resuspend cells, and cell viability was determined using trypan blue (Gibco).

\section{IFN- $\gamma$ ELISpot Assay}

After in vitro stimulation of splenocytes from immunized mice $\left(5 \times 10^{5}\right.$ cells/well) with $5 \mu \mathrm{M}$ of $18 \mathrm{HIV}-1$ peptides (either pooled or individual), an ELISpot assay was performed using a mouse IFN- $\gamma$ ELISpot Ready-SET-Go! Kit (eBioscience) according to the manufacturer's instructions. Expression of spot-forming units (SFU/ $10^{6}$ cells) was used to refer to the number of antigenspecific $\mathrm{T}$ lymphocytes and was calculated after subtracting values obtained for the unstimulated condition, and $15 \mathrm{SFU} / 10^{6}$ cells was considered as a cutoff.

\section{Cytometric Bead Array}

Splenocytes from immunized mice were cultured $\left(1 \times 10^{6}\right.$ cells/ well) with $5 \mu \mathrm{M}$ of pooled HIV-1 peptides for five days under an atmosphere of $5 \% \mathrm{CO}_{2}$ at $37^{\circ} \mathrm{C}$. Supernatants were harvested, and cytokines were detected using a Mouse Th1/Th2/Th17 Cytometric Bead Array Kit (BD) according to the manufacturer's instruction.

\section{Proliferation Assay}

To assess whether $\mathrm{T}$ lymphocytes from immunized animals proliferated in response to HIV-1-specific antigen, spleen cells were stained with $1.25 \mu \mathrm{M}$ of carboxyfluorescein succinimidyl ester (CFSE) and cultured (triplicates of $5 \times 10^{5}$ cells/well) with $5 \mu \mathrm{M}$ of pool of HIV-1 peptides or medium (R10) alone for five days under an atmosphere of $5 \% \mathrm{CO}_{2}$ at $37^{\circ} \mathrm{C}$. Cells were then collected and labeled for $30 \mathrm{~min}$ at $4^{\circ} \mathrm{C}$ with CD3 PE (145-2C11), CD4 PerCP (RM4-5), and CD8 APC (53-6.7) antimouse monoclonal antibodies (BD) for proliferation evaluation. After washing, samples were analyzed using a FACSCanto ${ }^{\mathrm{TM}}$ II (BD) with appropriate compensation controls (single stained beads, CompBeads (BD), or CFSE-single stained cells). The frequency of proliferating $\mathrm{T}$ lymphocyte subpopulations $\left(\mathrm{CFSE}^{\text {low }}\right.$ ) among $\mathrm{CD}^{+} \mathrm{CD}^{+}$or $\mathrm{CD}^{+} \mathrm{CD}^{+}$cells (Figure S1 in Supplementary Material) was determined using FlowJo software, version 9.7.6 (Tree Star). The HIV-specific population was determined by estimating the number of CFSE ${ }^{\text {low }}$ cells after HIV-1-specific stimulus and after subtracting values obtained for the unstimulated condition.

\section{Detection of Intracellular Cytokine Production}

To evaluate cytokine production from proliferating cells, spleen cells from immunized animals were stained with CFSE and cultured with $5 \mu \mathrm{M}$ of the pool of HIV-1 peptides or medium (R10) alone as described above. However, for the last $12 \mathrm{~h}$, cells were restimulated with the same antigen, $2 \mu \mathrm{g} / \mathrm{mL}$ of anti-CD28 (eBioscience) and Brefeldin A-GolgiPlug ${ }^{\mathrm{TM}}$ (BD). In the end, cells were collected and labeled with CD3 APC-Cy7 (145-2C11), CD4 PerCP (RM4-5), and CD8 Pacific Blue (53-6.7) antimouse monoclonal antibodies (BD) for $30 \mathrm{~min}$ at $4^{\circ} \mathrm{C}$. Cells were then fixed 
and permeabilized using a Cytofix/Cytoperm ${ }^{\mathrm{TM}}$ kit (BD) and then labeled with IL-2 PE (JES6-5H4), TNF- $\alpha$ PE-Cy7 (MP6-XT22) and IFN- $\gamma$ APC (XMG1.2) antimouse monoclonal antibodies (BD) for $30 \mathrm{~min}$ at $4^{\circ} \mathrm{C}$. After washing, samples were analyzed using a FACSCanto ${ }^{\mathrm{TM}}$ II (BD). The frequency of proliferating $\mathrm{T}$ cells that also produced each of the cytokines were determined by FlowJo software (Figure S1 in Supplementary Material). In addition, a Boolean gating platform was used to create all possible combinations of cytokine-producing cells.

\section{Cytotoxicity Assay}

Two groups of three to five mice were immunized with two doses of DNA HIVBr18 as described above, such that one group received no adjuvant, while the other received $70 \mu \mathrm{g}$ of $P$. acnes at the first dose only. Two weeks after the last immunization, the cell line RAW 264.7 (mouse leukemic monocyte macrophage) was cultured in six-well plates $\left(3 \times 10^{5}\right.$ cells/well $)$ under an atmosphere of $5 \% \mathrm{CO}_{2}$ at $37^{\circ} \mathrm{C}$ and maintained in $\mathrm{R} 10$ for $24 \mathrm{~h}$. After this period, the cells were transfected with $2 \mu \mathrm{L}$ of FuGENE ${ }^{\circledR} \mathrm{HD}$ Transfection Reagent (Promega) and $3 \mu \mathrm{g}$ of pVAX-HIVBr18 or $3 \mu \mathrm{g}$ of empty vector pVAX1 in Macrophage Medium (Gibco). After a 6-h incubation, R10 without antibiotic was added to each well. The next day, the culture medium was changed to R10 with [methyl- ${ }^{3} \mathrm{H}$ ] thymidine $(5 \mu \mathrm{Ci} / \mathrm{mL}$, Amersham Biosciences $)$. After $24 \mathrm{~h}$, transfected RAW 264.7 cells were collected after dissociation with $1 \%$ PBS-EDTA, and cellular concentration and viability were determined using trypan blue. Then, $1 \times 10^{4}$ of both transfected cells were cocultured with splenocytes from immunized mice at a 1:50 ratio of target to effector cells in 96-well round bottom plates to detect cytotoxicity (E) against target cells expressing or not expressing the HIV-1 antigen (transfected cells). Cells were incubated for $3.5 \mathrm{~h}$ under an atmosphere of $5 \% \mathrm{CO}_{2}$ at $37^{\circ} \mathrm{C}$ and were then collected using a cell harvester (PerkinElmer). A $\beta$-counter (MicroBeta $^{2}$ LumiJET-PerkinElmer) was used to measure radioactivity in counts per minute (CPM). Spontaneous lysis (S) was determined by culturing transfected cells alone in R10. The lysis percentage was calculated using the following equation:

$$
\% \text { Lysis }=[(\text { Scpm }- \text { Ecpm }) / \text { Scpm }] \times 100 .
$$

The specific lysis percentage was determined by subtracting the lysis value obtained when the target cell was transfected with pVAX-HIVBr18 (specific) from the lysis value obtained when the target cell was transfected with empty pVAX1 (unspecific).

\section{Data Analysis}

Significant differences between vaccinated groups were calculated by one-way analysis of variance followed by Tukey's Multiple Comparison Test using GraphPad Prism software.

\section{RESULTS}

\section{Broad, Specific, and Persistent T Cell Responses after HIVBr18 Immunization Coadministered with $P$ acnes}

To evaluate the adjuvant effect of $P$. acnes and whether its soluble PS fraction mediates bacterium action on the immunogenicity of HIVBr18, mice were administered the DNA vaccine alone or with the adjuvant in the first or in both doses. After 2 weeks, the cellular immune response was assessed, and compared to HIVBr18 alone (201 SFU/10 cells) and P. acnes in both doses (201.8 SFU $/ 10^{6}$ cells), addition of $P$. acnes to only the first dose was found to significantly increase the number of IFN- $\gamma$ producing cells (343.1 SFU $/ 10^{6}$ cells) (Figure 1A). In contrast, 10 weeks after the last dose, mice that received HIVBr18 with $P$. acnes in both doses expressed a higher number of IFN- $\gamma$-producing cells $(202.5$ $\mathrm{SFU} / 10^{6}$ cells) than the other mice $\left(87.3 \mathrm{SFU} / 10^{6}\right.$ cells for mice that did not receive adjuvant, and $76.4 \mathrm{SFU} / 10^{6}$ cells for mice that received $P$. acnes only in the first dose, Figure 1A). As expected, in animals immunized with empty vector pVAX1 in the presence of $P$. acnes, the number of these cells was lower than the cutoff value.

Human immunodeficiency virus-specific $\mathrm{T}$ cell proliferation analysis (Figure 1B) demonstrated that, 2 weeks postimmunization with HIVBr18, the presence of $P$. acnes in the first or in both doses enhanced the frequency of $\mathrm{CD} 4^{+} \mathrm{T}$ lymphocytes to a greater degree than the absence of adjuvant $(7.53,5.16$, and $2.51 \%$, respectively). Although the frequency of $\mathrm{CD}^{+}$proliferating $\mathrm{T}$ cells was also higher in the groups that received $P$. acnes, the group that received two doses of this adjuvant showed a significantly higher frequency (4.9\%) of proliferating cells than the group that received $P$. acnes with the first dose $(3.85 \%)$ and the group that received no adjuvant (1.83\%). Even 10 weeks after the last immunization, the presence of $P$. acnes in the first or in both doses induced a higher frequency of proliferation of HIV-1-specific CD4 ${ }^{+}$(6.35 and 6.69\%, respectively) and CD8 ${ }^{+}$ ( 6.07 and $7.38 \%$, respectively) $\mathrm{T}$ cells than the group that received no adjuvant $\left(4.10 \%\right.$ for $\mathrm{CD}^{+}$and $2.37 \%$ for $\mathrm{CD}^{+} \mathrm{T}$ cells). As expected, immunization with pVAX1 did not generate detectable HIV-1-specific T cell proliferation.

The addition of PS to HIVBr18 also increased the magnitude of IFN- $\gamma$ production (Figure 1C) 2 weeks after the last immunization when administered in the first dose (411 SFU/10 cells) and in both doses (495.6 SFU/10 cells). As expected, in pVAX1expressing mice that were immunized in the presence of PS, the number of IFN- $\gamma$-producing cells was below the cutoff value. Administration of PS in the first dose also induced higher HIV1 -specific $\mathrm{CD}^{+} \mathrm{T}$ cell proliferation $(4.73 \%)$ than the absence of adjuvant $(2.51 \%)$ and administration of PS in both doses $(2.56 \%)$ (Figure 1D). Regarding the $\mathrm{CD}^{+} \mathrm{T}$ cell component, the PS adjuvant effect was more prominent, such that administration of PS increased the frequency of these HIV-1-specific cells in both groups of animals that received PS (7.76 and 4.6\%, Figure 1D). As expected, spleen cells from pVAX1-immunized mice presented low levels of proliferation. However, different from $P$. acnes treatment, PS administration in the first or in both doses could not maintain the magnitude of the cellular response for 10 weeks, neither on IFN- $\gamma$ producing cells (121.7 and $129.3 \mathrm{SFU} / 10^{6}$ cells, Figure 1C) nor on the frequency of proliferating (Figure 1D) $\mathrm{CD}^{+}\left(2.63\right.$ and $3.63 \%$, respectively) and $\mathrm{CD}^{+} \mathrm{T}$ cells $(1.27$ and $1.73 \%$, respectively).

The breadth of the HIV-1-specific cellular response could be another factor indicating the effect of $P$. acnes as an adjuvant on the DNA vaccine HIVBr18 and the respective role of PS in this evaluation. Spleen cells from immunized mice were then 

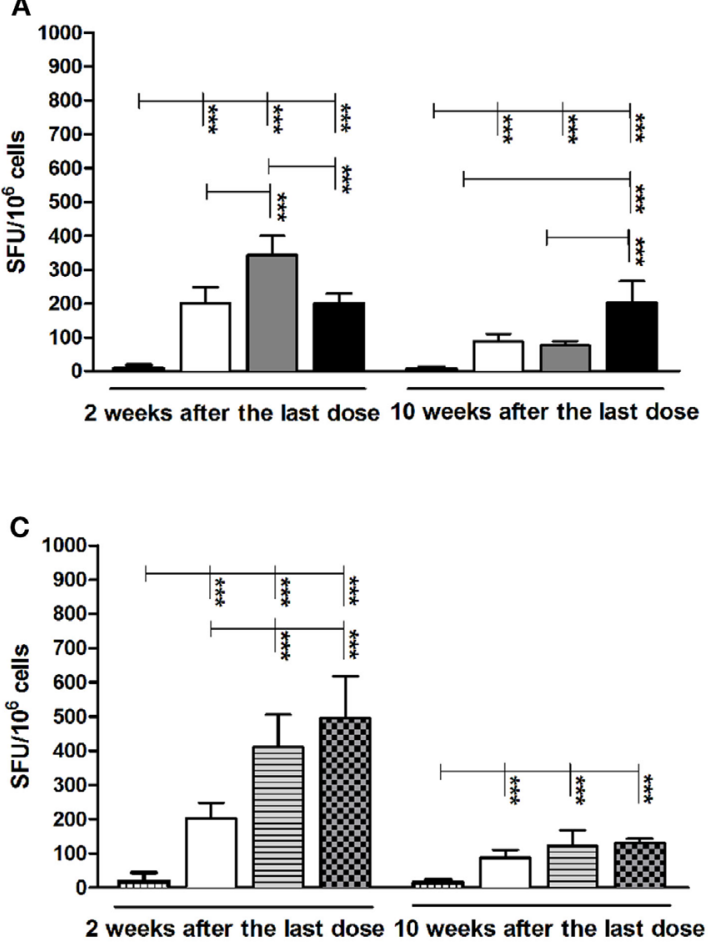
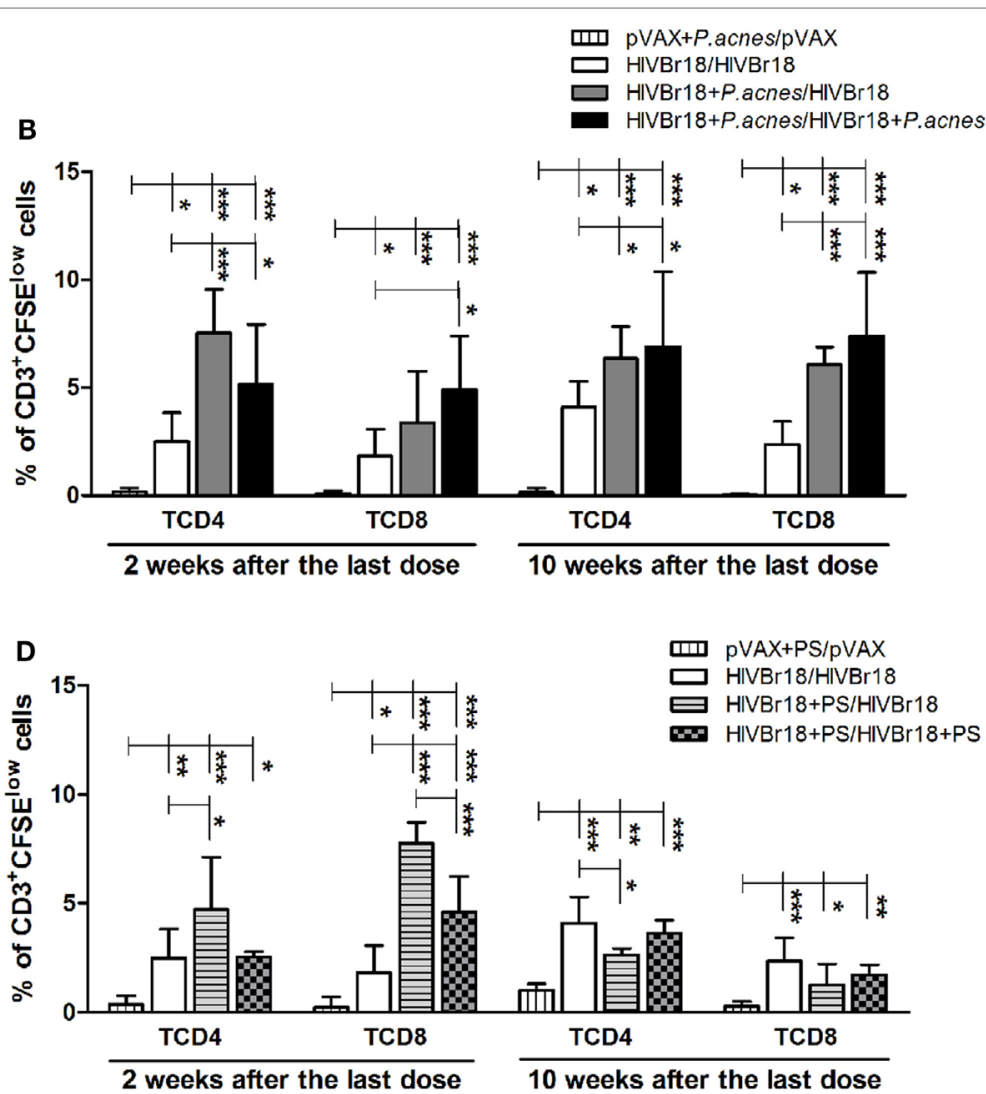

FIGURE 1 | The magnitude of specific cellular responses to the pool of human immunodeficiency virus (HIV)-1 peptides induced by HIVBr18 was potentiated and persisted when mice were immunized in the presence of Propionibacterium acnes. Two or 10 weeks after the last immunization with empty vector pVAX1 or HIVBr18, with or without $P$. acnes (A,B) or polysaccharide (C,D), splenocytes were either cultured for $18 \mathrm{~h}$ with pooled $\mathrm{HIV}-1$ peptides and evaluated for IFN- $\gamma$ production by ELISpot assay $(\mathbf{A}, \mathbf{C})$ or stained with carboxyfluorescein succinimidyl ester (CFSE) $(1.25 \mu \mathrm{M})$ before culturing with the pooled peptides for 5 days (B,D). Antigen-specific proliferation was defined by CFSE dilution in gated CD3 ${ }^{+} \mathrm{CD} 4^{+}$and $\mathrm{CD}^{+} \mathrm{CD} 8^{+}$cells by flow cytometry. SFU, spot-forming units. Cutoff $=15$ $\mathrm{SFU} / 10^{6}$ cells. Results are presented as values (mean $\pm \mathrm{SD}$ ) for each group from three independent experiments. ${ }^{\star} p<0.05 ;{ }^{* \star} p<0.001 ;{ }^{\star \star \star} p<0.0001$.

separately cultured in the presence of 1 of the 18 peptides encoded by HIVBr18. After 2 weeks, we detected that the breadth of the cellular response was significantly enhanced when HIVBr18 was delivered with P. acnes (Figure 2A) or PS (Figure 2D), which was indicated by the average of recognized peptides (Figures 2C,F). Splenocytes from mice immunized with $P$. acnes recognized 15 peptides, and of these 15, mice immunized with PS recognized 14, and mice immunized without adjuvant recognized 6. Moreover, the magnitude of the response to most of the recognized peptides, i.e., SFU value, was higher in the groups that received the adjuvants (Figures 2A,D). Thus, evaluating the HIV-1-specific response via IFN- $\gamma$ production, coadministration of $P$. acnes or PS was able to enhance not only the magnitude but also the range of the response.

Ten weeks after the last dose, only the group that received two doses of the DNA vaccine HIVBr18, both coadministered with $P$. acnes, sustained the closest number (14 peptides) of recognized peptides (Figure 2C). However, groups that received $P$. acnes only in the first dose, or received PS in one or both doses, responded to fewer peptides $(9,10$, and 11 peptides respectively, Figures 2C,F). Nevertheless, while the magnitude of positive peptide responses also remained high in both $P$. acnes groups (Figure 2B), this effect was not observed with PS (Figure 2E). Thus, even for the group that received a single dose of $P$. acnes and had a decrease in the number of peptides recognized over time, the magnitude of the positive peptides was still higher than that observed for PS.

\section{Improvement of the Th1 Response and the Polyfunctional Profile of the Cellular Immune Response After Coadministration of HIVBr18 with $P$. acnes or PS}

Results of the ELISpot assay for IFN- $\gamma$ revealed that the presence of $P$. acnes, or its PS component, in HIVBr18 immunization was able to induce a driven Th1 response. Thus, splenocyte culture supernatants were evaluated using a cytometric bead array to assess the cytokine profile (Figure 3 ). The presence of $P$. acnes (Figure 3A) in the first or in both doses generated significantly higher concentrations of IFN- $\gamma(4,012$ and $3,027 \mathrm{pg} / \mathrm{mL}$, respectively), IL-6 (408 and $249 \mathrm{pg} / \mathrm{mL}$, respectively), and TNF- $\alpha$ (185 pg/mL, when P. acnes was administered in the first dose), 

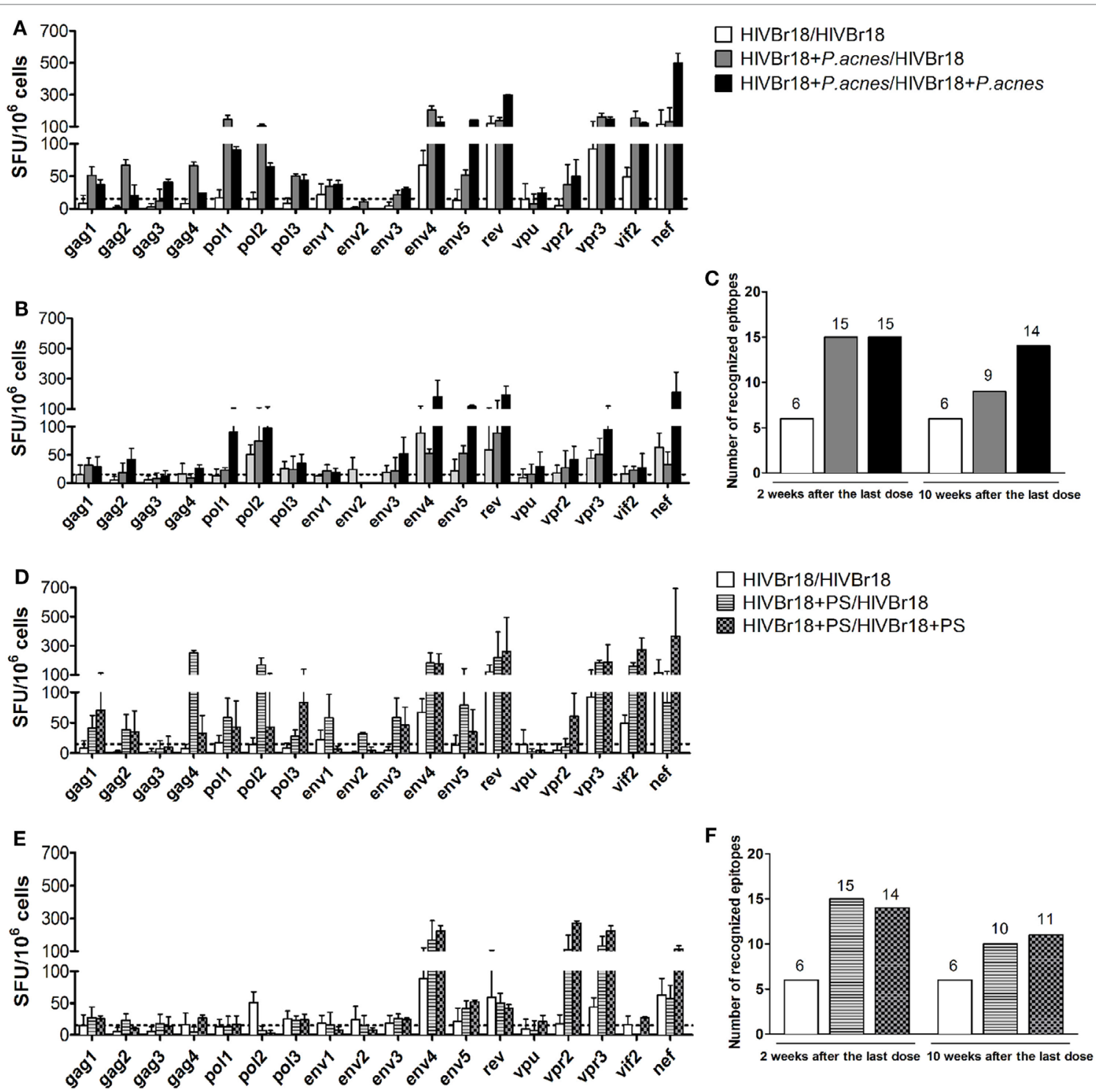

FIGURE 2 | Immunization with HIVBr18 in the presence of Propionibacterium acnes or its soluble polysaccharide (PS) fraction increased the magnitude and range of IFN- $\gamma$ production against the human immunodeficiency virus (HIV)-1 peptides, in a persistent manner. Two or 10 weeks after the last immunization with HIVBr18, in the presence of $P$. acnes [(A) for 2 weeks and (B) for 10 weeks] or PS [(D), for 2 weeks, and (E), for 10 weeks], spleen cells were separately cultured with each of the 18 peptides for $18 \mathrm{~h}$ and evaluated for the magnitude and range of IFN- $\gamma$ production by ELISpot assay. The number of recognized epitopes (C,F) was defined when IFN- $\gamma$ production was above the cutoff value. SFU, spot-forming units. Cutoff $=15 \mathrm{SFU} / 10^{6}$ cells (dotted line). Results are presented as values (mean \pm SD) from three independent experiments.

than the absence of adjuvant $(2,158,208$, and $123 \mathrm{pg} / \mathrm{mL}$, respectively). However, higher concentrations of IL-10 $(181 \mathrm{pg} / \mathrm{mL})$ and IL-17 $(390 \mathrm{pg} / \mathrm{mL})$ were detected with the absence of adjuvants (control group) than with the groups that received $P$. acnes in the first or in both doses (130 and $112 \mathrm{pg} / \mathrm{mL}$ for IL-10, and 157 and $215 \mathrm{pg} / \mathrm{mL}$ for IL-17). Levels of IL-4 and IL-2 cytokines were below the detection limit.

Coadministration of PS (Figure 3B) induced higher levels of type I cytokines, such as IFN- $\gamma$ and TNF- $\alpha$, than control group. However, compared to the level obtained with $P$. acnes treatment, there was an increase in the levels of IL-10 when PS was administered in the first or in both doses $(412$ and $298 \mathrm{pg} / \mathrm{mL}$, respectively) and of IL-17 (436 pg/mL) when PS was administered in the first dose.

To evaluate whether the adjuvant would affect the phenotypic and functional profile of HIV-1-specific T cells, we used multiparametric flow cytometry. As shown in Figure 4A, administration of $P$. acnes in the first dose of HIVBr18 induced a higher frequency of $\mathrm{CD}^{+} \mathrm{T}$ lymphocytes that proliferated and produced any combination of IFN- $\gamma$, IL-2, and TNF- $\alpha$ (3.22\%) than that induced by administration of HIVBr18 in the absence of adjuvant (2.1\%). In addition, Boolean combinations revealed that HIV immunization with $P$. acnes in the first dose increased the frequency of HIV-1-specific polyfunctional $\mathrm{CD}^{+} \mathrm{T}$ lymphocytes, 

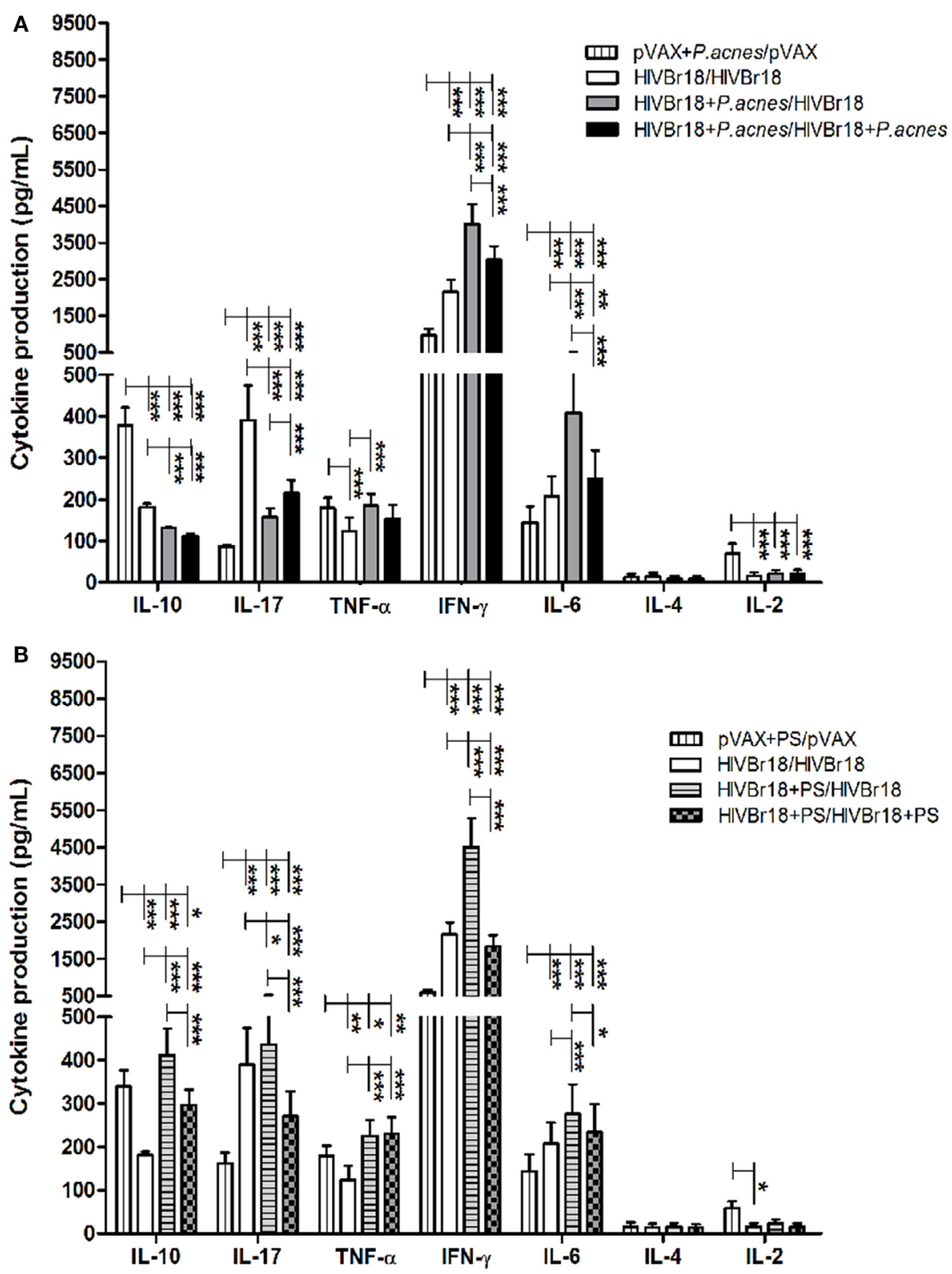

FIGURE 3 | Immunization with HIVBr18 in the presence of Propionibacterium acnes or polysaccharide (PS) increased the synthesis of Th1 cytokines against the pool of 18 peptides. Two weeks after immunization with empty vector pVAX1 or HIVBr18, in the presence or absence of $P$. acnes (A) or PS (B), splenocytes were cultured for five days with pooled human immunodeficiency virus (HIV)-1 peptides encoded by this DNA vaccine. Cytokines in the supernatant were analyzed using the mouse Th1/Th2/Th17 cytokine cytometric bead array (CBA, BD). Results are presented as values (mean \pm SD) from a representative experiment of three independent experiments. ${ }^{*} p<0.05 ;{ }^{* *} p<0.001 ;{ }^{* \star *} p<0.0001$.

as determined by the frequency of double positive IFN- $\gamma^{+} /$ TNF- $\alpha^{+}(1.09 \%)$ or triple positive $(0.51 \%)$ cells compared to that in other groups (Figure 4B). In turn, there was no difference in the $\mathrm{CD} 8^{+} \mathrm{T}$ cell population (Figures $4 \mathrm{C}, \mathrm{D}$ ) such that all groups exhibited proliferation of predominantly IFN- $\gamma$-producing cells. Similarly, the increase in polyfunctional $\mathrm{CD}^{+} \mathrm{T}$ lymphocytes was also observed with coadministration of PS, which increased the frequency of $\mathrm{CD}^{+} \mathrm{T}$ lymphocytes that proliferated and produced IFN- $\gamma$, IL-2, and TNF- $\alpha$ in any combination (Figure S2 in Supplementary Material).

\section{Cytotoxic Activity of Splenocytes Induced} by Immunization with HIVBr18 in

\section{Association to $P$ acnes}

As a functional evaluation of immunization with HIVBr18, the ability of splenocytes from immunized mice to induce the lysis of cells that potentially present HIV-1 peptides encoded by this DNA vaccine was investigated. Spleen cells obtained after the last immunization were cultured with a macrophage lineage (RAW 264.7) previously transfected with the HIVBr18 vaccine 


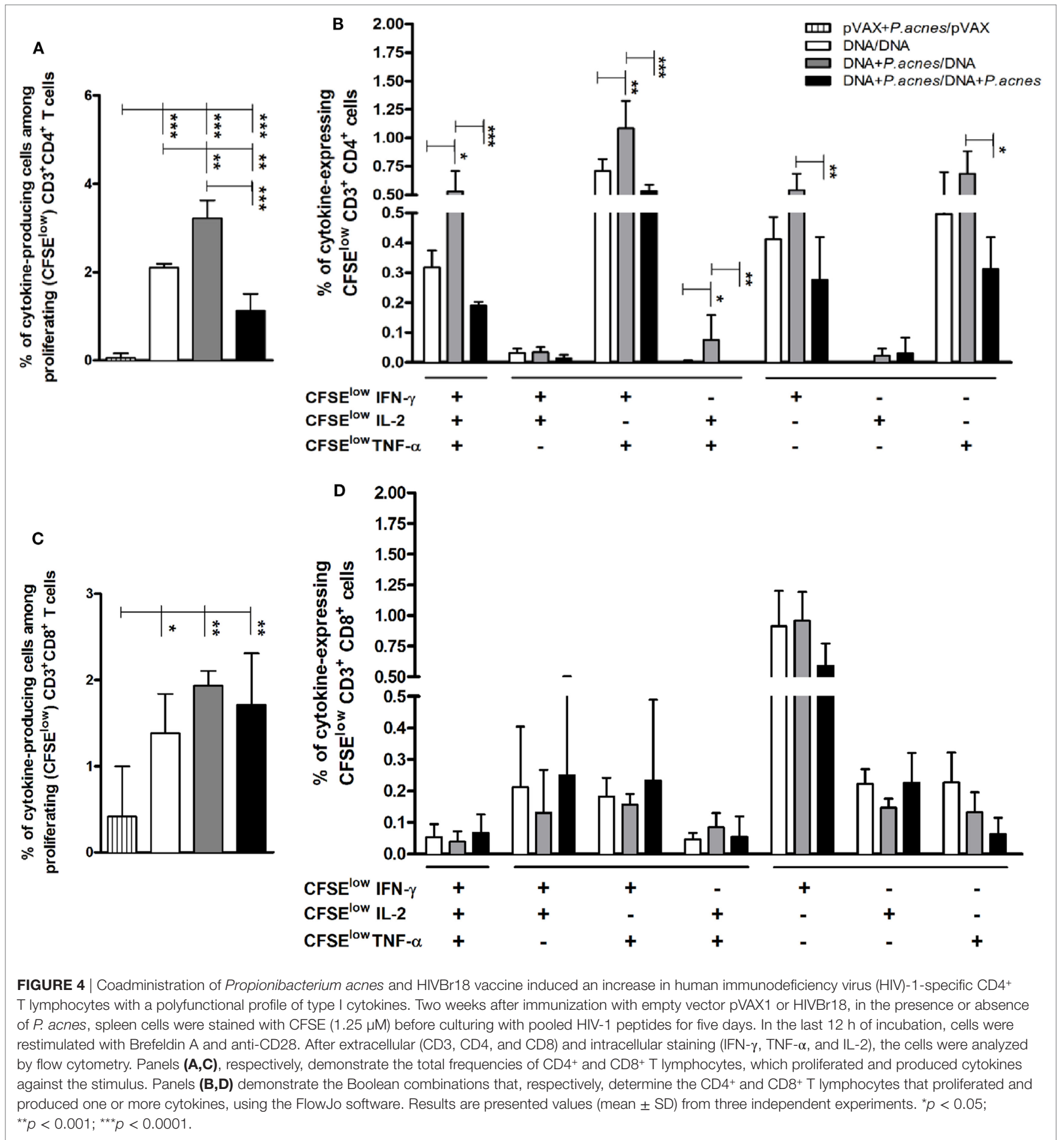

or with the empty vector and incubated with [methyl- $\left.{ }^{3} \mathrm{H}\right]$ thymidine.

The group that received $P$. acnes was found to be able to induce significant specific lysis (6.37\%) when compared to the group immunized with the DNA vaccine alone, which presented undetectable values of specific lysis (Figure 5).

\section{DISCUSSION}

Herein, we have demonstrated the adjuvant effect of heat-killed $P$. acnes suspension, which is known to induce a typical Th1 response, in the immunogenicity of HIVBr18. Specifically, $P$. acnes enhanced the magnitude and range of the response, 

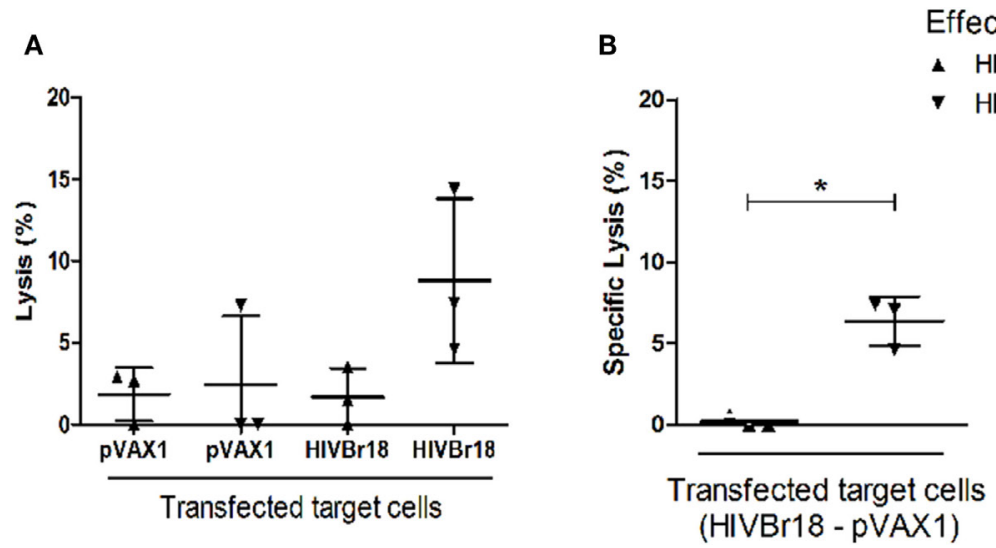

FIGURE 5 | Coadministration of Propionibacterium acnes and HIVBr18 DNA vaccine promoted cytotoxic activity of splenocytes against transfected cells. Two weeks after the last immunization with two doses of HIVBr18 alone, or with $P$. acnes in the first dose, spleen cells were obtained and cultured with a macrophage lineage that was previously transfected with the HIVBr18 vaccine plasmid or with empty vector (pVAX1), and then, samples were incubated with [methyl- ${ }^{3} \mathrm{H}$ ] thymidine. Cells were maintained at the proportion of 1 target to 50 effector cells under an atmosphere of $5 \% \mathrm{CO}_{2}$ at $37^{\circ} \mathrm{C}$ for $3.5 \mathrm{~h}$. Then, cells were collected in a cell harvester, and the radioactivity was measured in a $\beta$-counter and converted to lysis percentage (A). Specific lysis was evaluated by subtracting the lysis value obtained when target cells were transfected with HIVBr18 from the lysis value obtained when target cells were transfected with empty pVAX1 (B). Results are presented as values (mean $\pm \mathrm{SD}$ ) from a representative experiment of two independent experiments. ${ }^{*} p<0.05$.

increasing the number of recognized peptides. Moreover, even with few immunizations, this adjuvant increased the polyfunctional profile of $\mathrm{CD}^{+} \mathrm{T}$ cells and prolonged the vaccine-induced immune response. Furthermore, combining the adjuvant $P$. acnes with HIVBr18 immunization induced lymphocyte cytotoxicity to vaccine plasmid-transfected targets.

In this study, reduction in the number of doses used [comparable to the three-dose schedule demonstrated in previous studies $(23,24)$; Figure S3 in Supplementary Material], and the greater breadth of the response obtained by the coadministration the DNA vaccine and $P$. acnes could be explained by the direct action of this adjuvant on DCs, macrophages and B-2 lymphocytes, i.e., APCs, which has been previously described by us and others $(41,52,53,56)$. A DNA vaccine primes immune responses after intramuscular injection, transfecting mainly myocytes, as well as other immune cells found within the muscle, such as DCs and monocytes $(64,65)$. Transfection of these cells, or phagocytosis of transfected dead or dying cells by these cells, enables the generation of the immune response through $\mathrm{MHC}$ I and/or MHC II pathways, thus priming CTLs and activating $\mathrm{CD}^{+} \mathrm{T}$ helper lymphocytes (66-69). Therefore, we believe that the most appropriate adjuvant for DNA vaccine should be the one that potentiates APCs.

Direct effects of $P$. acnes on DC maturation have been described in vitro (52-54) and in vivo, such that previous studies observed an increase in DC precursors in the liver and blood of mice after treatment with $P$. acnes $(70,71)$ and an increase in the number and activation status of bone marrow-derived DCs (56). The function of P. acnes and the role of its soluble PS component in the activation status of these cells and other APCs have been well investigated. In a murine model of hypersensitivity to ovalbumin (OVA), potentiation of the Th2 response occurred when $P$. acnes or PS treatment coincided with OVA administration, but a typical Th1 response occurred when mice were treated with the adjuvant before OVA sensitization $(55,57)$. The potentiated OVA-Th2 responses induced by $P$. acnes and PS rely on directed cytokine production, a significant increase in the number of APCs expressing costimulatory molecules, such as CD40 (except PS), CD80, and CD86, and upregulation of these three molecules by mainly macrophages and DCs. However, when Th2 was suppressed, increased expression levels of TLR2, TLR4 and intracellular TLR9 in B cells and DCs and extracellular TLR9 in B cells and macrophages, with increasing numbers of IL- $12^{+}$cells, were observed. Several studies demonstrated the relationship between TLR2 and TLR4 signaling and the induction of Th1 or suppression of Th2 responses in allergic diseases (72-75). It was also shown that innate immune cells could be directly activated by $P$. acnes via TLR2 and TLR9 $(48,49)$, thus inducing proinflammatory cytokine synthesis (76). Moreover, $P$. acnes is known to induce production of proinflammatory cytokines, such as IL-18 (77-80), and in combination with IL-12, IL-18 may be responsible for directing the $\mathrm{T}$ helper response, resulting in IFN- $\gamma$ secretion. Therefore, we can speculate that the influence of this adjuvant on APCs-such as improving the cell-mediated immune response (evaluated by IFN- $\gamma$ production and $\mathrm{T}$ cell proliferation), increasing the response magnitude and significantly improving the response range (by increasing the number of recognized peptides) - can explain its impact on the immunogenicity of the HIVBr18 vaccine.

A broad T cell response against conserved epitopes is an essential condition for protection, as demonstrated by $\mathrm{T}$ cell-based HIV vaccine trials $(20,81,82)$. For example, in the STEP trial, an adenovirus 5-based HIV vaccine encoding three HIV proteins (Gag, Pol, and Nef) induced an average recognition of only three epitopes per participant but in conserved and variable regions of the sequence. This vaccine failed to reduce the viral load in infected individuals and to prevent HIV-1 infection $(20,82,83)$. In addition, the induction of simultaneous, vaccine-specific $\mathrm{CD} 4^{+}$ 
and $\mathrm{CD}^{+} \mathrm{T}$ cell responses was limited to $25 \%$ of the patients. However, an adenovirus 5-based SIV vaccine encoding eight SIV proteins promoted a broad $\mathrm{CD}^{+}$and $\mathrm{CD} 8^{+} \mathrm{T}$ lymphocyte response in vaccinated non-human primates, allowing viremia control after challenge (84).

Unmethylated regions of DNA-such as cytosine-phosphateguanine oligonucleotide sequences ( $\mathrm{CpG}$ ), which are also common in bacterial genomes-incorporated into DNA vaccines are recognized by TLR9 and induce APC-dependent production of proinflammatory cytokines, i.e., IL-12 and IFN type I, and thus, these regions act as an immune response adjuvant $(85,86)$. Similarly, $P$. acnes effects are associated with the induction and activation of intracellular and extracellular TLR9 in APCs $(49,58)$ by inducing the release of Th1 cytokines (87) and IgG2a switch, which is also related to the Th1 pattern (88). This direction to the Th1 pattern was observed both in the Th2 suppression in the type I hypersensitivity murine model described above and using a DNA vaccine containing T. cruzi trans-sialidase gene when a higher synthesis of IFN- $\gamma$ and reduction of IgG1/IgG2a ratio (41) were demonstrated. Indeed, coadministration of HIVBr18 and $P$. acnes increased IFN- $\gamma$ and TNF- $\alpha$ production but decreased IL-10 production, confirming the Th1 pattern generated by this vaccine (24) and suggesting a greater Th1 polarization upon coadministration of $P$. acnes. Interestingly, immunization with a DNA vaccine in the presence of $P$. acnes led to a decrease in vaccine-specific IL-17 cytokine levels. Moreover, the Th17 response during HIV infection is controversial (89). IL-17A is involved in maintaining the integrity of the epithelial barrier $(90,91)$, and depletion of gut-associated lymphoid tissue Th17 and Th1/Th17 lymphocytes was shown to be the main cause of chronic immune activation and non-AIDS-related comorbidities in infected individuals (92). However, Th17 cells have been shown to be pathogenic due to their permissiveness to viral infection because they carry integrated HIV-DNA and contribute to persistent reservoirs of HIV under antiretroviral treatment $(89,93)$.

Intensive investigations of adjuvants that increase the immunogenicity of DNA vaccination have previously demonstrated that coadministration of cytokine genes significantly enhances the immune response $(60,94-97)$. In a recent work, coadministration of the HIVBr18 DNA vaccine and a plasmid encoding granulocyte-macrophage colony-stimulating factor (GM-CSF) (60) increased the frequency of polyfunctional HIV-specific T lymphocytes (IFN- $\gamma^{+}$TNF- $\alpha^{+}$IL- $\left.2^{+}\right)$. As such, these findings may be related to the increase in these polyfunctional cells observed following coadministration of HIVBr18 and P. acnes. A previous study reported an increase in the synthesis of hematopoietic cytokines, such as GM-CSF, in animals treated with $P$. acnes (98), when then induced an increase in the number of bone marrow stem cells and the maturation of DCs (56). HIVspecific and polyfunctional $\mathrm{CD} 4^{+} \mathrm{T}$ lymphocytes were shown to be more frequent in long-term non-progressor patients than in patients who rapidly progressed to $\operatorname{AIDS}(99,100)$. Therefore, the polyfunctional responses of $\mathrm{HIV}$-specific $\mathrm{CD} 4^{+} \mathrm{T}$ cells might be potentiated by the presence of $P$. acnes and might contribute to the control of disease progression (101-106). We also observed higher levels of Th1 cytokines when $P$. acnes was administered in the first dose than when it was administered in both doses. This result could be explained due to cytokine receptor exhaustion or even their delayed turnover.

The levels of IFN- $\gamma$-producing cells and proliferating HIVspecific $\mathrm{CD}^{+}$and $\mathrm{CD}^{+} \mathrm{T}$ lymphocytes 10 weeks after the last dose demonstrated that the coadministration of $P$. acnes with both HIV-1 vaccinations is important for longevity of the cellular response. The $\mathrm{CD}^{+} \mathrm{T}$ lymphocyte response was previously reported to persist for up to 24 weeks when the DNA vaccine was administered in three doses with a central memory element (24). A vaccine capable of inducing $\mathrm{CD}^{+}$and $\mathrm{CD}^{+}$effector memory responses was previously shown to also prevent progressive systemic infection in animals challenged with highly pathogenic SIV, even in the absence of neutralizing antibodies (107). Therapeutic vaccination of monkeys with SIV-specific DNA vaccine with coadministration of IL-12 and IL-15 plasmids enhanced the specific population of $\mathrm{CD}^{+}$memory cells and their production of cytokines (97). Modulation of both innate and acquired immunity by inducing proinflammatory cytokines, including IL-12, may be one of the mechanisms by which $P$. acnes could modulate the population of memory cells (108), and this mechanism may be associated with the higher frequency of IFN- $\gamma$-producing cells and the increased number of recognized peptides.

As expected and as demonstrated in our previous studies, herein, PS is one of the main components of $P$. acnes responsible for the outcomes observed when using the whole bacterium. PS substantially increased the number of cells that specifically produced IFN- $\gamma$ and increased the amplitude of recognized peptides, the frequency of HIV-specific T lymphocytes (especially the CD8 ${ }^{+}$ population), the cytokine pattern (regarding the production of type I cytokines), and the number of $\mathrm{CD} 4^{+}$polyfunctional T cells. The presence of other compounds in the whole bacterium (proteins and lipids) could explain the differences observed between $P$. acnes and PS treatments, notably the absence of a significant cognate memory $\mathrm{T}$ cell population and a persistent cellular response. However, as demonstrated in previous studies, PS had an undeniable effect in inducing TLR2, TLR4, extracellular and intracellular TLR9 in APCs and B-1 cells $(58,109)$.

We also found that immunization with the HIVBr18 vaccine, in the presence of $P$. acnes, induced an increased HIV-1-specific cytotoxic activity against target cells transfected with the same plasmid. These target cells could express the majority of epitopes encoded by the DNA vaccine, and herein, the effector cells were found to be able to respond to a large spectrum of epitopes when the adjuvant was coadministered with the vaccine. This activity could be explained by the induction of the Th1 response pattern by the effector pool when $P$. acnes was administered. In addition to these mediators of the adaptive immune response, the adjuvantpotentiated increase in IFN- $\gamma$ levels could also affect cells with cytotoxic activities, such as macrophages, NK and NKT cells. Published data from our laboratory and others have shown an increased cytotoxic activity of macrophages and NKT cells with high levels of TNF- $\alpha$ and NO release induced by $P$. acnes and its PS fraction $(36-38,110)$.

A DNA vaccine, such as HIVBr18 vaccine, can induce a potent and persistent response of $\mathrm{CD}^{+}{ }^{+} \mathrm{T}$ cells with a polyfunctional phenotype and thus can facilitate the cytotoxic activity of these cells. As previously shown in the literature, this type of DNA 
vaccine may have a protective effect against SIV/HIV infection $(15,18,19,22,84,99-106)$. In summary, the adjuvant effect of coadministration of $P$. acnes with HIVBr18 was evidenced by the potentiation of these responses and the increase in the number of recognized peptides, which generated a broader and more persistent response and reduced the number of administered doses. Given the promising use of $P$. acnes in humans, the enhanced responses against conserved $\mathrm{HIV}-1$ regions, such as those observed by coadministering HIVBr18 and P. acnes, might control viral replication in individuals who became infected after immunization not only by limiting viral transmission but also by preventing progression to HIV-associated disease.

\section{ETHICS STATEMENT}

This study was carried out in strict accordance with the recommendations of the National Institutes of Health Guide for the Care Use of Laboratory Animals and the Brazilian National Law (11.794/2008). The protocol was approved by the Institutional Animal Care and Use Committee (IACUC) of the Federal University of São Paulo and by the Ethics Committee of University of São Paulo School of Medicine (permit number 4836281114).

\section{AUTHOR CONTRIBUTIONS}

DT and IM conceived and designed the experiments. DT, MI, JA, JV, and VP performed the experiments. DT, MI, JV, and

\section{REFERENCES}

1. Gallo RC, Salahuddin SZ, Popovic M, Shearer GM, Kaplan M, Haynes BF, et al. Frequent detection and isolation of cytopathic retroviruses (HTLV-III) from patients with AIDS and at risk for AIDS. Science (1984) 224:500-3. doi:10.1126/science.6200936

2. Barre-Sinoussi F, Chermann JC, Rey F, Nugeyre MT, Chamaret S, Gruest J, et al. Isolation of a T-lymphotropic retrovirus from a patient at risk for acquired immune deficiency syndrome (AIDS). Science (1983) 220:868-71. doi:10.1126/science.6189183

3. UNAIDS/WHO 2016. AIDS by the Numbers. AIDS Is not Over, But It Can Be. (2016) Available from: http://www.unaids.org/sites/default/files/ media_asset/AIDS-by-the-numbers-2016_en.pdf

4. Simon V, Ho DD, Abdool Karim Q. HIV/AIDS epidemiology, pathogenesis, prevention, and treatment. Lancet (2006) 368:489-504. doi:10.1016/ S0140-6736(06)69157-5

5. McMichael AJ, Borrow P, Tomaras GD, Goonetilleke N, Haynes BF. The immune response during acute HIV-1 infection: clues for vaccine development. Nat Rev Immunol (2010) 10:11-23. doi:10.1038/nri2674

6. Gandhi RT, Walker BD. Immunologic control of HIV-1. Annu Rev Med (2002) 53:149-72. doi:10.1146/annurev.med.53.082901.104011

7. Carmichael A, Jin X, Sissons P, Borysiewicz L. Quantitative analysis of the human immunodeficiency virus type I (HIV-1)-specific cytotoxic T lymphocyte (CTL) response at different stages of HIV-1 infection: differential CTL responses to HIV-1 and Epstein-Barr virus in late disease. J Exp Med (1993) 177:249-56. doi:10.1084/jem.177.2.249

8. Connor RI, Mohri H, Cao Y, Ho DD. Increased viral burden and cytopathocity correlate temporally with $\mathrm{CD} 4^{+} \mathrm{T}$-lymphocyte decline and clinical progression in human immunodeficiency virus type 1-infected individuals. J Virol (1993) 67:1772-7.

9. McElrath MJ, Haynes BF. Induction of immunity to human immunodeficiency virus type-1 by vaccination. Immunity (2010) 33:542-54. doi:10.1016/j. immuni.2010.09.011
VP analyzed the data and prepared the figures. DT, MI, and IM wrote the manuscript. IM, DR, and EC-N performed the final review of the article. All authors read and approved the final article.

\section{ACKNOWLEDGMENTS}

The authors would like to thank Mr. Geová Santos for animal care at UNIFESP/EPM. The authors also thank Renato Arruda Mortara and Carina Carrara for providing the RAW 264.7 cell line and FuGENE ${ }^{\circledR}$ HD Transfection Reagent for cytotoxicity assays.

\section{FUNDING}

This research was supported by the Fundação de Amparo à Pesquisa do Estado de São Paulo (FAPESP, 2014/25307-4), Conselho Nacional de Desenvolvimento Científico e Tecnológico $(\mathrm{CNPq})$ and Coordenação de Aperfeiçoamento de Pessoal de Nível Superior (CAPES).

\section{SUPPLEMENTARY MATERIAL}

The Supplementary Material for this article can be found online at https://www.frontiersin.org/articles/10.3389/fimmu.2018.00177/ full\#supplementary-material.

10. Klatt NR, Silvestri G. CD4 ${ }^{+}$T cells and HIV: a paradoxical pas de deux. Sci Transl Med (2012) 4:123s4. doi:10.1126/scitranslmed.3003862

11. Shedlock DJ, Shen H. Requirement for CD4 T cell help in generating functional CD8 T cell memory. Science (2003) 300:337-9. doi:10.1126/ science. 1082305

12. Lichterfeld M, Kaufmann DE, Yu XG, Mui SK, Addo MM, Johnston MN, et al. Loss of HIV-1-specific CD8 ${ }^{+} \mathrm{T}$ cell proliferation after acute HIV-1 infection and restoration by vaccine-induced HIV-1-specific CD4 ${ }^{+} \mathrm{T}$ cells. J Exp Med (2006) 200:701-12. doi:10.1084/jem.20041270

13. Rosenberg ES, Billingsley JM, Caliendo AM, Boswell SL, Sax PE, Kalams SA, et al. Vigorous HIV-1-specific CD4 $\left(^{+}\right)$T cell responses associated with control of viremia. Science (1997) 278:1447-50. doi:10.1126/science.278. 5342.1447

14. Norris PJ, Moffett HF, Yang OO, Kaufmann DE, Clark MJ, Addo MM, et al. Beyond help: direct effector functions of human immunodeficiency virus type 1-specific CD4 $\left({ }^{+}\right)$T cells. J Virol (2004) 78:8844-51. doi:10.1128/ JVI.78.16.8844-8851.2004

15. Sacha JB, Giraldo-Vela JP, Buechler MB, Martins MA, Maness NJ, Chung C, et al. Gag- and Nef-specific CD4 $\left(^{+}\right) \mathrm{T}$ cells recognize and inhibit SIV replication in infected macrophages early after infection. Proc Natl Acad Sci U S A (2009) 106:9791-6. doi:10.1073/pnas.0813106106

16. Von Gegerfelt A, Valentin A, Alicea C, Van Rompay KK, Marthas ML, Montefiori DC, et al. Emergence of simian immunodeficiency virus-specific cytotoxic $\mathrm{CD}^{+} \mathrm{T}$ cells and increased humoral responses correlate with control of rebounding viremia in CD8-depleted macaques infected with Revindependent live-attenuated simian immunodeficiency virus. J Immunol (2010) 185:3348-58. doi:10.4049/jimmunol.1000572

17. Pancre V, Delhem N, Yazdanpanah Y, Delanoye A, Delacre M, Depil S, et al. Presence of HIV-1 Nef specific CD4 T cell response is associated with non-progression in HIV-1 infection. Vaccine (2007) 25:5927-37. doi:10.1016/j.vaccine.2007.05.038

18. Soghoian DZ, Jessen H, Flanders M, Sierra-Davidson K, Cutler S, Pertel T, et al. HIV-specific cytolytic CD4 T cell responses during acute 
HIV infection predict disease outcome. Sci Transl Med (2012) 4:123-5. doi:10.1126/scitranslmed.3003165

19. Vaccari M, Mattapallil J, Song K, Tsai WP, Hryniewicz A, Venzon D, et al. Reduced protection from simian immunodeficiency virus SIVmac251 infection afforded by memory $\mathrm{CD} 8+\mathrm{T}$ cells induced by vaccination during $\mathrm{CD} 4+$ T-cell deficiency. J Virol (2008) 82(19):9629-38. doi:10.1128/JVI.00893-08

20. Sekaly RP. The failed HIV Merck vaccine study: a step back or a launching point for future vaccine development? J Exp Med (2008) 205:7-12. doi:10.1084/jem.20072681

21. Watkins DI. The hope for an HIV vaccine based on induction of $\mathrm{CD} 8\left(^{+}\right)$ T lymphocytes-a review. Mem Inst Oswaldo Cruz (2008) 103:119-29. doi:10.1590/S0074-02762008000200001

22. Fonseca SG, Coutinho-Silva A, Fonseca LA, Segurado AC, Moraes SL, Rodrigues $\mathrm{H}$, et al. Identification of novel consensus $\mathrm{CD} 4 \mathrm{~T}$-cell epitopes from clade B HIV-1 whole genome that are frequently recognized by HIV-1 infected patients. AIDS (2006) 20:2263-73. doi:10.1097/01.aids.0000253353.48331.5f

23. Ribeiro SP, Rosa DS, Fonseca SG, Mairena EC, Postól E, Oliveira SC, et al. A vaccine encoding conserved promiscuous HIV CD4 epitopes induces broad $\mathrm{T}$ cell responses in mice transgenic to multiple common HLA class II molecules. PLoS One (2010) 5:6. doi:10.1371/journal.pone.0011072

24. Rosa DS, Ribeiro SP, Almeida RR, Mairena EC, Postól E, Kalil J, et al. A DNA vaccine encoding multiple HIV CD4 epitopes elicits vigorous polyfunctional, long-lived $\mathrm{CD} 4\left(^{+}\right)$and $\mathrm{CD} 8\left(^{+}\right) \mathrm{T}$ cell responses. PLoS One (2011) 6:2. doi:10.1371/journal.pone.0016921

25. Apostolopoulos V, Weiner DB. Development of more efficient and effective DNA vaccines. Expert Rev Vaccines (2009) 8(9):1133-4. doi:10.1586/erv.09.94

26. Hokey DA, Weiner DB. DNA vaccines for HIV: challenges and opportunities. Springer Semin Immunopathol (2006) 28(3):267-79. doi:10.1007/ s00281-006-0046-z

27. Laddy DJ, Yan J, Corbitt N, Kobasa D, Kobinger GP, Weiner DB, et al. Immunogenicity of novel consensus-based DNA vaccines against avian influenza. Vaccine (2007) 25(16):2984-9. doi:10.1016/j.vaccine.2007.01.063

28. Schoenly KA, Weiner DB. Human immunodeficiency virus type 1 vaccine development: recent advances in the cytotoxic T-lymphocyte platform "spotty business". J Virol (2008) 82(7):3166-80. doi:10.1128/JVI.01634-07

29. Joseph S, Quinn K, Greenwood A, Cope AV, McKay PF, Hayes PJ, et al. A comparative phase I study of combination, homologous subtype-C DNA, MVA, and Env gp140 protein/adjuvant HIV vaccines in two immunization regimes. Front Immunol (2017) 8:149. doi:10.3389/fimmu.2017.00149

30. Leyden JJ, McGinley KJ, Mills O, Kligman AM. Age-related changes in the resident bacterial flora of the human face. J Invest Dermatol (1974) 65:379-81. doi:10.1111/1523-1747.ep12607630

31. Molife R, Hancock BW. Adjuvant therapy of malignant melanoma. Crit Rev Oncol Hematol (2002) 44:81. doi:10.1016/S1040-8428(02)00014-8

32. Shepherd FA. Alternatives to chemotherapy and radiotherapy as adjuvant treatment for lung cancer. Lung Cancer (1997) 17(Suppl 1):S121. doi:10.1016/ S0169-5002(97)00646-6

33. Halpern BN, Pr'Evot AR, Biozzi G, Stiffel C, Mouton D, Morard JC, et al. [Stimulation of the phagocytic activity of the reticuloendothelial system by Corynebacterium parvum]. J Reticuloendothel Soc (1964) 83:77-96.

34. Woodruff MF, McBride WH, Dunbar N. Tumour growth, phagocytic activity and antibody response in Corynebacterium parvum-treated mice. Clin Exp Immunol (1974) 17:509-18.

35. Halpern BN, Biozzi G, Stiffel C, Mouton D. Inhibition of tumour growth by administration of killed Corynebacterium parvum. Nature (1966) 212:853-4. doi:10.1038/212853a0

36. Ghaffar A, Cullen RT, Woodruff MA. Further analysis of the anti-tumour effect in vitro of peritoneal exudate cells from mice treated with Corynebacterium parvum. Br J Cancer (1975) 31:15-24. doi:10.1038/bjc.1975.3

37. Keller R, Keist R, van der Meide PH. Modulation of tumoricidal activity, induced in bone-marrow-derived mononuclear phagocytes by interferon gamma or Corynebacterium parvum, by interferon beta, tumor necrosis factor, prostaglandin E2, and transforming growth factor beta. Int J Cancer (1991) 49:796-800. doi:10.1002/ijc.2910490526

38. Ananias RZ, Rodrigues EG, Braga EG, Squaiella CC, Mussalem JS, Longhini ALF, et al. Modulatory effect of killed-Propionibacterium acnes and its purified soluble polysaccharide on peritonial exudate cells from C57Bl/6 mice: major NKT cell recruitment and increased cytotoxicity. Scand J Immunol (2007) 65:538-48. doi:10.1111/j.1365-3083.2007.01939.x
39. Kennedy JD, Sutton RC, Conley FK. Effect of intracerebrally injected Corynebacterium parvum on the development and growth of metastatic brain tumor in mice. Neurosurgery (1989) 25:709-14. doi:10.1227/00006123198911000-00004

40. Warr GW, James K. Effect of Corynebacterium parvum on the class and subclass of antibody produced in the response of different strains of mice to sheep erythrocytes. Immunology (1975) 28:431-42.

41. Mussalem JS, Vasconcelos JR, Squaiella CC, Ananias RZ, Braga EG, Rodrigues MM, et al. Adjuvant effect of the Propionibacterium acnes and its purified soluble polysaccharide on the immunization with plasmidial DNA containing a Trypanosoma cruzi gene. Microbiol Immunol (2006) 50:253-63. doi:10.1111/j.1348-0421.2006.tb03791.x

42. Nussenzweig R. Increased nonspecific resistance to malaria produced by administration of killed Corynebacterium parvum. Exp Parasitol (1967) 21:224. doi:10.1016/0014-4894(67)90084-7

43. Brener Z, Cardoso JE. Nonspecific resistance against Trypanosoma cruzi enhanced by Corynebacterium parvum. JParasitol (1967) 62:645-6. doi: $10.2307 / 3279437$

44. Ha DK, Lawton JW, Gardner ID. The effect of in vivo modulation of macrophage activities on Mycobacterium lepraemurium infection. J Comp Pathol (1986) 96:565-73. doi:10.1016/0021-9975(86)90077-0

45. Hill JO. Modulation of the pattern of development of experimental disseminated leishmaniasis by Corynebacterium parvum. J Leukoc Biol (1986) 41:165-9. doi:10.1002/jlb.41.2.165

46. Abath FG, Coutinho EM, Montenegro SM, Gomes YM, Carvalho AB. The use of non-specific immunopotentiators in experimental Trypanosoma cruzi infection. Trans R Soc Trop Med Hyg (1988) 82:73-6. doi:10.1016/ 0035-9203(88)90268-4

47. Squaiella CC, Braga EG, Ananias RZ, Longhini ALF, Mussalem JS, Silva RM, et al. Longo-Maugéri, I. M. Efeito do tratamento de camundongos com Propionibacterium acnes sobre a resposta específica e atividade de células do sistema imune na infecção por Klebsiella pneumoniae. Anais do IX Congresso de Iniciação Científica - PIBIC. (Vol. 1), São Paulo, Brazil (2001). 7 p.

48. Kim J, Ochoa MT, Krutzik SR, Takeuchi O, Uematsu S, Legaspi AJ, et al. Activation of toll-like receptor 2 in acne triggers inflammatory cytokine responses. J Immunol (2002) 169:1535-41. doi:10.4049/jimmunol.169.3.1535

49. Kalis C, Gumenscheimer M, Freudenberg N, Tchaptchet S, Fejer G, Heit A, et al. Requirement for TLR9 in the immunomodulatory activity of Propionibacterium acnes. J Immunol (2005) 174:4295-300. doi:10.4049/ jimmunol.174.7.4295

50. Velayudham A, Hritz I, Dolganiuc A, Mondrekar P, Kurt-Jones E, Szabo G. Critical role of Toll-like receptors and the common TLR adaptor, MyD88, in induction of granulomas and liver injury. J Hepatol (2006) 45:813-24. doi:10.1016/j.jhep.2006.06.017

51. Gambero M, Teixeira D, Butin L, Ishimura ME, Mariano M, Popi AF, et al. Propionibacterium acnes induces an adjuvant effect in B-1 cells and affects their phagocyte differentiation via a TLR2-mediated mechanism. Immunobiology (2006) 221(9):1001-11. doi:10.1016/j.imbio.2016.03.003

52. MacDonald AS, Straw AD, Bauman B, Pearce EJ. CD8-dendritic cell activation status plays an integral role in influencing Th2 response development. J Immunol (2001) 167:1982-8. doi:10.4049/jimmunol.167.4.1982

53. MacDonald AS, Straw AD, Dalton NM, Pearce EJ. Cutting edge: Th2 response induction by dendritic cells: a role for CD40. J Immunol (2002) 168:537-40. doi:10.4049/jimmunol.168.2.537

54. Cervi L, MacDonald AS, Kane C, Dzierszinski F, Pearce EJ. Cutting edge: dendritic cells copulsed with microbial and helminth antigens undergo modified maturation, segregate the antigens to distinct intracellular compartments, and concurrently induce microbe-specific Th1 and helminthspecific Th2 responses. J Immunol (2004) 172:2016-20. doi:10.4049/jimmunol. 172.4.2016

55. Squaiella CC, Longhini ALF, Braga EG, Mussalem JS, Ananias RZ, Yendo TM, et al. Modulation of the type I hypersensitivity late phase reaction to OVA by Propionibacterium acnes-soluble polysaccharide. Immunol Lett (2008) 121:157-66. doi:10.1016/j.imlet.2008.10.005

56. Squaiella CC, Ananias RZ, Mussalem JS, Braga EG, Rodrigues EG, Travassos LR, et al. In vivo and in vitro effect of killed Propionibacterium acnes and its purified soluble polysaccharide on mouse bone marrow stem cells and dendritic cell differentiation. Immunobiology (2006) 211:105-16. doi:10.1016/j.imbio.2005.10.013 
57. Braga EG, Ananias RZ, Mussalem JS, Squaiella CC, Longhini AL, Mariano M, et al. Treatment with Propionibacterium acnes modulates the late phase reaction of immediate hypersensitivity in mice. Immunol Lett (2003) 88:163-9. doi:10.1016/S0165-2478(03)00079-8

58. Squaiella-Baptistão CC, Teixeira D, Mussalem JS, Ishimura ME, LongoMaugéri IM. Modulation of Th1/Th2 immune responses by killedPropionibacterium acnes and its soluble polysaccharide fraction: induction of different activation status of antigen-presenting cells. J Immunol Res (2015) 132083:14. doi:10.1155/2015/132083

59. Ribeiro SP, Apostolico JS, Almeida RR, Kalil J, Cunha-Neto E, Rosa DS. Bupivacaine enhances the magnitude and longevity of HIV-specific immune response after immunization with a CD4 epitope-based DNA vaccine. Trials Vaccinol (2014) 3:95-101. doi:10.1016/j.trivac.2014.05.001

60. Santana VC, Almeida RR, Ribeiro SP, Ferreira LC, Kalil J, Rosa DS, et al. Co-administration of plasmid-encoded granulocyte-macrophage colonystimulating factor increases human immunodeficiency virus-1 DNA vaccine-induced polyfunctional CD4+ T-cell responses. Mem Inst Oswaldo Cruz (2015) 110(8):1010-6. doi:10.1590/0074-02760150283

61. Bradford MM. A rapid and sensitive method for the quantitation of microgram quantities of protein utilizing the principle of protein-dye binding. Anal Biochem (1976) 72:248. doi:10.1016/0003-2697(76)90527-3

62. Palmer JW, Gerlough TD. Scientific apparatus and laboratory methods. Science (1940) 92:155-6. doi:10.1126/science.92.2381.155

63. Dubois M, Gilles KA, Hamilton JK, Rebers PA, Smith FA. Colorimetric method for the determination of sugars. Nature (1951) 28:167. doi:10.1038/168167a0

64. Dupuis M, Denis-Mize K, Woo C, Goldbeck C, Selby MJ, Chen M, et al. Distribution of DNA vaccines determines their immunogenicity after intramuscular injection in mice. J Immunol (2000) 165(5):2850-8. doi:10.4049/ jimmunol.165.5.2850

65. Chattergoon MA, Kim JJ, Yang JS, Robinson TM, Lee DJ, Dentchev T, et al. Targeted antigen delivery to antigen-presenting cells including dendritic cells by engineered Fas-mediated apoptosis. Nat Biotechnol (2000) 18(9):974-9. doi:10.1038/79470

66. Rubartelli A, Poggi A, Zocchi MR. The selective engulfment of apoptotic bodies by dendritic cells is mediated by the alpha(v)beta3 integrin and requires intracellular and extracellular calcium. Eur J Immunol (1997) 27(8):1893-900. doi:10.1002/eji.1830270812

67. Albert ML, Pearce SF, Francisco LM, Sauter B, Roy P, Silverstein RL, et al. Immature dendritic cells phagocytose apoptotic cells via alphavbeta5 and CD36, and cross-present antigens to cytotoxic T lymphocytes. J Exp Med (1998) 188(7):1359-68. doi:10.1084/jem.188.7.1359

68. Harshyne LA, Zimmer MI, Watkins SC, Barratt-Boyes SM. A role for class A scavenger receptor in dendritic cell nibbling from live cells. J Immunol (2003) 170(5):2302-9. doi:10.4049/jimmunol.170.5.2302

69. Steinman RM, Pope M. Exploiting dendritic cells to improve vaccine efficacy. J Clin Invest (2002) 109(12):1519-26. doi:10.1172/JCI15962

70. Yoneyama H, Matsuno K, Zhang Y, Murai M, Itakura M, Ishikawa S, et al. Regulation by chemokines of circulating dendritic cell precursors, and the formation of portal tract-associated lymphoid tissue, in a granulomatous liver disease. J Exp Med (2001) 193:35-49. doi:10.1084/jem.193.1.35

71. Zhang Y, Yoneyama H, Wang Y, Yshikawa S, Hashimoto S, Gao JL, et al. Mobilization of dendritic cell precursors into the circulation by administration of MIP-1alpha in mice. J Natl Cancer Inst (2004) 96:201-9. doi:10.1093/ jnci/djh024

72. Braun-Fahrländer C, Riedler J, Herz U, Eder W, Waser M, Grize L, et al. Environmental exposure to endotoxin and its relation to asthma in school-age children. N Engl J Med (2002) 347(12):869-77. doi:10.1056/NEJMoa020057

73. Lauener RP, Birchler T, Adamski J, Braun-Fahrländer C, Bufe A, Herz U, et al. Expression of CD14 and toll-like receptor 2 in farmers' and non-farmers' children. Lancet (2002) 360(9331):465-6. doi:10.1016/S0140-6736(02)09641-1

74. Taylor RC, Richmond P, Upham JW. Toll-like receptor 2 ligands inhibit TH2 responses to mite allergen. J Allergy Clin Immunol (2006) 117(5):1148-54. doi:10.1016/j.jaci.2006.02.014

75. Rodríguez D, Keller AC, Faquim-Mauro EL, de Macedo MS, Cunha FQ, Lefort J, et al. Bacterial lipopolysaccharide signaling through toll-like receptor 4 suppresses asthma-like responses via nitric oxide synthase 2 activity. J Immunol (2003) 171(2):1001-8. doi:10.4049/jimmunol.171.2.1001

76. Takeda K, Kaisho T, Akira S. Toll-like receptors. Annu Rev Immunol (2003) 21:335-76. doi:10.1146/annurev.immunol.21.120601.141126
77. Smith SR, Calzetta A, Bankowski J, Kenworthy BL, Terminelli C. Lipopolysaccharide-induced cytokine production and mortality in mice treated with Corynebacterium parvum. JLeukoc Biol (1993) 54:23-9. doi:10.1002/jlb.54.1.23

78. Okamura H, Tsutsui H, Komatsu T, Yutsudo M, Hakura A, Tanimoto T, et al. Cloning of a new cytokine that induces IFN-gamma production by $\mathrm{T}$ cells. Nature (1995) 378:88-91. doi:10.1038/378088a0

79. Matsui K, Yoshimoto T, Tsutsui H, Hyodo Y, Hayashi N, Hiroishi K, et al. Propionibacterium acnes treatment diminishes $\mathrm{CD} 4^{+} \mathrm{NK} 1.1^{+} \mathrm{T}$ cells in the liver by induction of IL-12 and IL-18 production from Kupffer cells. J Immunol (1997) 159:97-106.

80. Tsuji H, Mukaida N, Harada A, Kaneko S, Matsushita E, Nakanuma Y, et al. Alleviation of lipopolysaccharide-induced acute liver injury in Propionibacterium acnes-primed INF-gamma-deficient mice by a concomitant reduction of TNF-alpha, IL-12 and IL-18 production. J Immunol (1999) 162:1049-55.

81. Watkins DI, Burton DR, Kallas EG, Moore JP, Koff WC. Nonhuman primate models and the failure of the Merck HIV-1 vaccine in humans. Nat Med (2008) 14:617-21. doi:10.1038/nm.f.1759

82. McElrath MJ, De Rosa SC, Moodie Z, Dubey S, Kierstead L, Janes H, et al. HIV-1 vaccine-induced immunity in the test-of-concept step study: a case-cohort analysis. Lancet (2008) 372:1894-905. doi:10.1016/S0140-6736(08)61592-5

83. Corey L, McElrath MJ, Kublin JG. Post-step modifications for research on HIV vaccines. AIDS (2009) 23:3-8. doi:10.1097/QAD.0b013e32830e6d6d

84. Wilson NA, Keele BF, Reed JS, Piaskowski SM, MacNair CE, Bett AJ, et al. Vaccine-induced cellular responses control simian immunodeficiency virus replication after heterologous challenge. J Virol (2009) 83:6508-21. doi:10.1128/JVI.00272-09

85. Hemmi H, Takeuchi O, Kawai T, Kaisho T, Sato S, Sanjo H, et al. A tolllike receptor recognizes bacterial DNA. Nature (2000) 408(6813):740-5. doi:10.1038/35047123

86. Tudor D, Dubuquoy C, Gaboriau V, Lefevre F, Charley B, Riffault S. TLR9 pathway is involved in adjuvant effects of plasmid DNA-based vaccines. Vaccine (2005) 23(10):1258-64. doi:10.1016/j.vaccine.2004.09.001

87. Bauer S, Hangel D, Yu P. Immunobiology of toll-like receptors in allergic disease. Immunobiology (2007) 212(6):521-33. doi:10.1016/j.imbio.2007.03.011

88. Jegerlehner A, Maurer P, Bessa J, Hinton HJ, Kopf M, Bachmann MF. TLR9 signaling in B cells determines class switch recombination to IgG2a. J Immunol (2007) 178(4):2415-20. doi:10.4049/jimmunol.178.4.2415

89. Wacleche VS, Goulet JP, Gosselin A, Monteiro P, Soudeyns H, Fromentin R, et al. New insights into the heterogeneity of Th17 subsets contributing to HIV-1 persistence during antiretroviral therapy. Retrovirology (2016) 13(1):59. doi:10.1186/s12977-016-0293-6

90. Lee JS, Tato CM, Joyce-Shaikh B, Gulan F, Cayatte C, Chen Y, et al. Interleukin23-Independent IL-17 production regulates intestinal epithelial permeability. Immunity (2015) 43(4):727-38. doi:10.1016/j.immuni.2015.09.003

91. Maxwell JR, Zhang Y, Brown WA, Smith CL, Byrne FR, Fiorino M, et al. Differential roles for interleukin-23 and interleukin-17 in intestinal immunoregulation.Immunity (2015) 43(4):739-50. doi:10.1016/j.immuni.2015.08.019

92. Sandler NG, Douek DC. Microbial translocation in HIV infection: causes, consequences and treatment opportunities. Nat Rev Microbiol (2012) 10:655-66. doi:10.1038/nrmicro2848

93. Sun H, Kim D, Li X, Kiselinova M, Ouyang Z, Vandekerckhove L, et al. Th1/17 Polarization of CD4 T cells supports HIV-1 persistence during antiretroviral therapy. J Virol (2015) 89:11284-93. doi:10.1128/JVI.01595-15

94. Hanlon L, Argyle D, Bain D, Nicolson L, Dunham S, Golder MC, et al. Feline leukemia virus DNA vaccine efficacy is enhanced by coadministration with interleukin-12 (IL-12) and IL-18 expression vectors. J Virol (2001) 75(18):8424-33. doi:10.1128/JVI.75.18.8424-8433.2001

95. Piedrafita D, Xu D, Hunter D, Harrison RA, Liew FY. Protective immune responses induced by vaccination with an expression genomic library of Leishmania major. J Immunol (1999) 163(3):1467-72.

96. Xiang R, Primus FJ, Ruehlmann JM, Niethammer AG, Silletti S, Lode HN, et al. A dual-function DNA vaccine encoding carcinoembryonic antigen and $\mathrm{CD} 40$ ligand trimer induces $\mathrm{T}$ cell-mediated protective immunity against colon cancer in carcinoembryonic antigen-transgenic mice. J Immunol (2001) 167(8):4560-5. doi:10.4049/jimmunol.167.8.4560

97. Halwani R, Boyer JD, Yassine-Diab B, Haddad EK, Robinson TM, Kumar S, et al. Therapeutic vaccination with simian immunodeficiency virus 
(SIV)-DNA+ IL-12 or IL-15 induces distinct CD8 memory subsets in SIV-infected macaques. J Immunol (2008) 180(12):7969-79. doi:10.4049/ jimmunol.180.12.7969

98. Foster RS, MacPherson BR, Browdie DA. Effect of Corynebacterium parvum on colony-stimulating factor and granulocyte-macrophage colony formation. Cancer Res (1997) 37:1349-55.

99. Okoye A, Park H, Rohankhedkar M, Coyne-Johnson L, Lum R, Walker JM, et al. Profound CD4+/CCR5+ T cell expansion is induced by CD8+ lymphocyte depletion but does not account for accelerated SIV pathogenesis. J Exp Med (2009) 206:1575-88. doi:10.1084/jem.20090356

100. Virgin HW, Walker BD. Immunology and the elusive AIDS vaccine. Nature (2010) 464:224-31. doi:10.1038/nature08898

101. Kannanganat S, Kapogiannis BG, Ibegbu C, Chennareddi L, Goepfert P, Robinson HL, et al. Human immunodeficiency virus type 1 controllers but not noncontrollers maintain CD4 T cells coexpressing three cytokines. J Virol (2007) 81:12071-6. doi:10.1128/JVI.01261-07

102. Ferre AL, Hunt PW, Critchfield JW, Young DH, Morris MM, Garcia JC, et al. Mucosal immune responses to HIV-1 in elite controllers: a potential correlate of immune control. Blood (2009) 113:3978-89. doi:10.1182/blood-200810-182709

103. Ferre AL, Hunt PW, McConnell DH, Morris MM, Garcia JC, Pollard RB, et al. HIV controllers HLA-DRB1 ${ }^{\star} 13$ and HLA-DQB1 ${ }^{\star} 06$ have strong, polyfunctional mucosal CD4+ T-cell responses. J Virol (2010) 84(21):11020-9. doi:10.1128/JVI.00980-10

104. Harari A, Petitpierre S, Vallelian F, Pantaleo G. Skewed representation of functionally distinct populations of virus-specific CD4 T cells in HIV1 -infected subjects with progressive disease: changes after antiretroviral therapy. Blood (2004) 103:966-72. doi:10.1182/blood-2003-04-1203

105. Emu B, Sinclair E, Hatano H, Ferre A, Shacklett B, Martin JN, et al. HLA class I restricted T-cell responses may contribute to the control of human immunodeficiency virus infection, but such responses are not always necessary for long-term virus control. J Virol (2008) 82:5398-407. doi:10.1128/ JVI.02176-07
106. Rosa DS, Ribeiro SP, Fonseca SG, Almeida RR, Santana VC, Apostólico Jde S, et al. Multiple approaches for increasing the immunogenicity of an epitope-based anti-HIV vaccine. AIDS Res Hum Retroviruses (2015) 31(11):1077-88. doi:10.1089/AID.2015.0101

107. Hansen SG, Vieville C, Whizin N, Coyne-Johnson L, Siess DC, Drummond DD, et al. Effector memory $\mathrm{T}$ cell responses are associated with protection of rhesus monkeys from mucosal simian immunodeficiency virus challenge. Nat Med (2009) 15:293-9. doi:10.1038/nm.1935

108. Chowdhury FZ, Ramos HJ, Davis LS, Forman J, Farrar JD. IL-12 selectively programs effector pathways that are stably expressed in human CD8+ effector memory T cells in vivo. Blood (2011) 118(14):3890-900. doi:10.1182/ blood-2011-05-357111

109. Mussalem JS, Squaiella-Baptistão CC, Teixeira D, Yendo TM, Thies FG, Popi AF, et al. Adjuvant effect of killed Propionibacterium acnes on mouse peritoneal B-1 lymphocytes and their early phagocyte differentiation. PLoS One (2012) 7(3):e33955. doi:10.1371/journal.pone.0033955

110. Longhini ALF, Mussalem JS, Takahashi H, Straus A, Longo-Maugéri IM. Soluble polysaccharide from Propionibacterium acnes with biological effects. Scand J Immunol (2001) 54(Suppl1):90.

Conflict of Interest Statement: The authors declare that the research was conducted in the absence of any commercial or financial relationships that could be construed as a potential conflict of interest.

Copyright (C) 2018 Teixeira, Ishimura, Apostólico, Viel, Passarelli, Cunha-Neto, Rosa and Longo-Maugéri. This is an open-access article distributed under the terms of the Creative Commons Attribution License (CC BY). The use, distribution or reproduction in other forums is permitted, provided the original author(s) and the copyright owner are credited and that the original publication in this journal is cited, in accordance with accepted academic practice. No use, distribution or reproduction is permitted which does not comply with these terms. 